\title{
Innovative technology for insulating the borehole absorbing horizons with thermoplastic materials
}

\author{
Andrii Sudakov ${ }^{1 *}$, Ihor Chudyk $^{2}$, Diana Sudakova ${ }^{1}$, and Liudmyla Dziubyk ${ }^{3}$ \\ ${ }^{1}$ Dnipro University of Technology, Department of Technic Prospecting of Mineral Deposits, \\ 19 Yavornytskoho Ave., 49005 Dnipro, Ukraine \\ ${ }^{2}$ Ivano-Frankivsk National Technical University of Oil and Gas, Department Drilling of the Wells, \\ 15 Karpatska St., 76019 Ivano-Frankivsk, Ukraine \\ ${ }^{3}$ Lviv Polytechnic National University, Department of Technical Mechanics and Dynamics of \\ Machines, 12 S. Bandery St., 79013 Lviv, Ukraine
}

\begin{abstract}
The purpose of the work is to increase the insulation work efficiency by using thermoplastic mixes based on polyethylene terephthalate. The tasks set were solved by a complex method of research, including the analysis and synthesis of the literary and patent sources, as well as conducting the analytical and experimental studies. The experimental data were processed on a PC using the methods of mathematical statistics. A method for insulating the absorbing horizons with thermoplastic materials has been developed and substantiated. To implement it, the following technological operations should be performed: supply of the thermoplastic materials to the borehole bottom, melting and squeezing of thermoplastic materials into absorption channels. For various geological and technical conditions of drilling, technological schemes of insulating the absorbing horizons with thermoplastic materials are proposed. The use of the household waste based on polyethylene terephthalate has been proposed as the plugging material to insulate the absorbing horizons of boreholes. For the first time, the possibility of using the household waste based on polyethylene terephthalate as the plugging thermoplastic material has been substantiated and proved. For the first time, a method for determining the efficient range of technology application for absorbing and unstable horizons insulation with thermoplastic materials through the use of bottom hole thermal sources has been substantiated analytically.
\end{abstract}

\section{Relevance of the topic}

Drilling, both exploration and production wells for the purpose of exploration deposits and mining in the area of iron ore and coal basins are being conducted to a high degree of development and metamorphism, in hard and fractured rocks [1 - 10]. Breeds of developed horizons are in a complex stress state $[11-18]$. This only decompounds the technology of

\footnotetext{
* Corresponding author: sudakovy@ukr.net
} 
the construction of mine workings [19-22].

The process of drilling wells is connected with geological problems. A common problem is the absorption of washing fluid [23]. On liquidation of absorptions a considerable amount of time and money are spent from the total cost of drilling wells. Absorption leads to an infraction of the technological regime of boring, the integrity of the wells walls and provokes accidents [24 - 28].

\section{Analysis of last research and determination of unsolved problems}

Research in the field of development of plugging materials and technologies of the prevention absorption of the drilling fluid is dedicated to the work Basaryhina Yu.M., Brazhenenka A.M., Bulatova A.I, Vasylieva M.I., Vakhrameieva I.I., Vozdvizhenskoho B.I., Haivoronskoho O.O., Dotsenka Yu.H., Ivacheva L.M., Kypka E.Ia., Kotskulycha Ya.S., Krylova V.I., Kudriashova B.B., Lipatova M.K., Martynenka I.I., Mysliuka M.A., Nikolaieva M.I., Polozova Yu.A., Rafienka I.I., Spychaka Yu.N., Sudakova A.K., Stavychnoho Ye.M., Tershaka B.A., Tytkova N.I., Tiana P.M., Yakovlieva A.M., Yasova V.H. and other scholars. An analysis of their works was performed in [29-32].

The process of drilling wells is associated with geological complications. The most frequent type of complications that violates the technology of drilling is the absorption drilling fluid, at the same time, the annual cost of time in the overall balance for drilling increased to $23 \%$ and funds up to $10 \%$.

Analysis of the conducted research shows that there is now a great variety of technologies and materials for the dissolution of fluid loss (Fig. 1) [31]. In most cases, the elimination of absorption is ensured by the laying of channels. Absorption of washing fluid with hardening or non-hardening tampon mixtures creates a waterproof screen in the rock around the well. The use of plugging materials, which are prepared on a water-based basis with the infiltration of mineral or synthetic substances into their composition, are not sufficiently effective to eliminate the absorption of washing fluids. In our opinion, these materials and technologies have exhausted their potential of further improvement. Therefore, the only way is to design and apply technologies based on anhydrous materials, and other processes of formation of a plugging stone for the formation of insulation veils. These technologies include technology of creation of a plugging stone, based on the phenomenon of phase transition.

Mixtures of thermoplastic materials based on bitumen, sulfur and synthetic thermoplastics (polyethylene, polypropylene) have been used until nowadays [33, 34]. But due to the imperfection of technology, the use of thermoplastic materials was not widely used as plugging materials in isolation of absorbing horizons of drilling wells. In order to solve the problem of isolation of absorbing horizons, it is necessary to find fundamentally new solutions. Therefore, the development of technologies for the isolation of absorbing horizons with the use of more effective plugging materials is extremely important.

The work is devoted to solve this urgent scientific task, which consists in the establishment of regularities changes in axial load and rotational speed when substantiating the regime parameters effective thermomechanical isolation technology of absorbing horizons from the middle limit strength on uniaxial compression depending on: composite composition, ratio components and type of filler; melt temperature overheating, density, time hardening and the number of melting plugging thermoplastic composite materials, which has a great practical importance.

The purpose and objectives of this research. The aim of the work is to improve the thermomechanical technology of isolation of absorbing horizons of drilling wells by establishing regularities of change and substantiation of its regime parameters from the 
composition and physical and mechanical properties of the plugging thermoplastic composite material and, on this basis, to develop a technological regulation to contain recommendations on the manufacture of composites and the organization of plugging works, to design and to isolate an absorption zones of the washing fluid in drill holes.

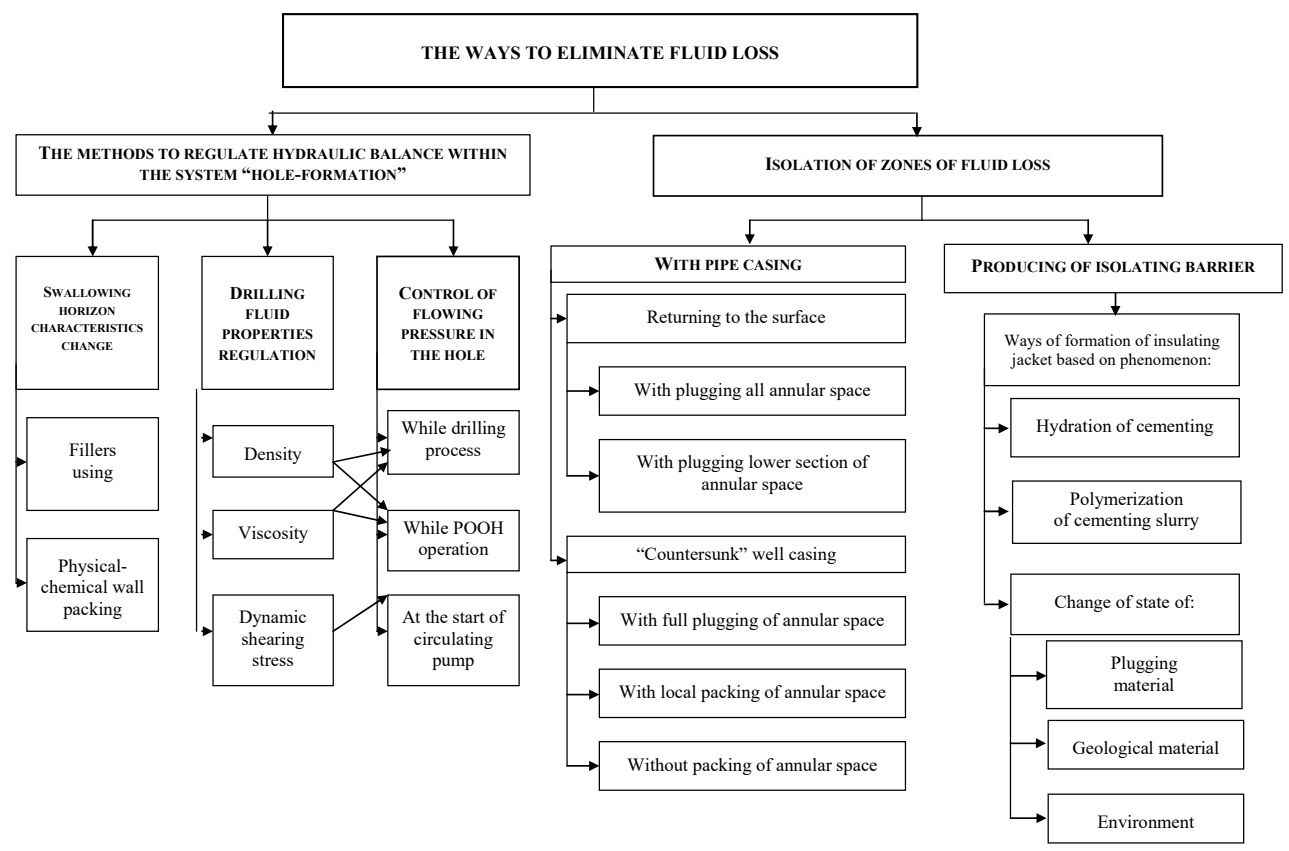

Fig. 1. Classification of the ways to eliminate the loss of drilling fluid.

The idea of the work is to establish and use the regularities of changing the physical and mechanical properties and advantages of the plugging thermoplastic composite material to justify the regime parameters and introduce into the production of an effective thermomechanical technology for the isolation of absorbing horizons of drill holes.

\section{Basic material}

A new technology for the isolation of TPM absorbing horizons based on the use of polyethylene terephthalate [ $35-39$ ] is proposed to eliminate the disadvantages inherent in TPM application technologies. A distinctive feature of the technology is that the TPM delivered to the zone of complication in the form of a cylindrically-hollow cylinder, is melting under the influence of positive temperatures of the downhole contact type heat source, followed by crushing the polymer into the absorbing horizon and cooling it to form an impenetrable, low-volume insulation sheath [40 - 43] .

To implement the proposed technology, it is necessary to perform the following technological operations, step by step: transporting the TPM to the absorbing horizon through the wellbore, melting TPM and pushing the TPM into the absorption channels. Other ways for the implementation of this technology are given in Table 1. [44]

The application of the designed technology is the isolation of swallowing horizons in the boreholes of various purposes, presented by stable crystalline rocks with a full, intense or catastrophic fluid loss. 
The field of application of the technology is the isolation of absorbing horizons in boreholes for various purposes, represented by stable, crystalline rocks with complete, intensive or catastrophic absorption of washing fluid.

Table 1. Insulation technology absorbing horizons TPM

\begin{tabular}{|l|l|}
\hline \multicolumn{1}{|c|}{ Process steps } & \multicolumn{1}{c|}{ Possible variants of steps } \\
\hline \multirow{3}{*}{$\begin{array}{l}\text { Transporting the TPM } \\
\text { to the swallowing } \\
\text { horizon }\end{array}$} & Along the hole \\
\cline { 2 - 2 } & On the drill-stem \\
\cline { 2 - 2 } & Along the drill-stem \\
\hline \multirow{3}{*}{ TPM melting } & In in pod \\
\cline { 2 - 2 } & By fire \\
\cline { 2 - 2 } & By chemicals \\
\hline \multirow{2}{*}{ TPM squeezing } & By bottom-hole electrical heater \\
\cline { 2 - 2 } & By bottom-hole electrical heater \\
\hline
\end{tabular}

It is proposed to use polyethylene terephthalate (PET) as a plugging thermoplastic material. The physical properties of polyethylene terephthalate are given in Table $2[38,39$, $45-47]$.

PET is one of the most common polymers. About 65 million tons of various products (fibers, threads, films, bottles, etc.) are produced from PET in the world. One of the important reasons for such a rapid development of PET production is that of all types of synthetic polymers its production is the most environmentally friendly, since the only byproduct of the process of its production is the reaction water. The main stages of the manufacturing process are carried out in a vacuum, and therefore there are practically no emissions to the environment.

Table 2. Physical properties of polyethylene terephthalate.

\begin{tabular}{|l|c|c|}
\hline \multicolumn{1}{|c|}{ Property } & Unit & Value \\
\hline Density: & & 1.33 \\
\hline - amorphous PET & $\mathrm{g} / \mathrm{cm}^{3}$ & 1.45 \\
\hline - crystalline PET & $\mathrm{g} / \mathrm{cm}^{3}$ & $1.38-1.40$ \\
\hline - both amorphous and crystalline PET & $\mathrm{g} / \mathrm{cm}^{3}$ & \\
\hline Break point: & & 172 \\
\hline - ultimate tensile strength & $\mathrm{MPa}$ & $50-70$ \\
\hline - transverse strength & $\mathrm{MPa}$ & $80-120$ \\
\hline - compressing strength & $\mathrm{MPa}$ & $1.41 \cdot 10^{4}$ \\
\hline Modulus of tensile elasticity & $\mathrm{MPa}$ & $12-55$ \\
\hline Ultimate elongation & $\%$ & 30 \\
\hline Impact elasticity & $\mathrm{kJ} / \mathrm{m}^{2}$ & $100-120$ \\
\hline Brinnel hardness & $\mathrm{MPa}$ & 0.3 \\
\hline Water adsorption for $24 \mathrm{~h}$ & $\%$ & $255-265$ \\
\hline Temperature of fusion & ${ }^{\circ} \mathrm{C}$ & $245-248$ \\
\hline Softening point & ${ }^{\circ} \mathrm{C}$ & 350 \\
\hline Breakdown temperature & ${ }^{\circ} \mathrm{C}$ & $6.55 \cdot 10^{-4}$ \\
\hline Factor of thermal expansion & & 0.14 \\
\hline Thermal conductance & $\mathrm{W} / \mathrm{mK}$ & -50 \\
\hline Freezing resistance & ${ }^{\circ} \mathrm{C}$ & 3.1 \\
\hline Dielectric capacitivity at $10^{6} \mathrm{~Hz}$ & & \\
\hline
\end{tabular}


PET waste belongs to class 5 (the safest) and dioxins are not released when incinerated, since PET does not contain chlorine. The toxicity of PET when burning is identical to burning firewood.

In connection with the separate collection of municipal solid waste introduced in Ukraine, the use of recycled PET should sharply increase, from which about 50 thousand tons / year of various types of textile products are already produced in Ukraine.

Polyethylene terephthalate is a synthetic linear thermoplastic polymer belonging to the class of polyesters. Polycondensation product of terephthalic acid and monoethylene glycol. Polyethylene terephthalate has the ability to exist in amorphous or crystalline states, and the degree of crystallinity is determined by the thermal history of the material.

With rapid cooling, polyethylene terephthalate is amorphous. Amorphous polyethylene terephthalate is a solid transparent material. Commercial polyethylene terephthalate is usually produced in the form of granules with a granule size of 2-4 millimeters.

PET has high mechanical strength (Table 2) and impact resistance, abrasion resistance and multiple deformations under tension and bending. It retains its high impact and strength characteristics in the operating temperature range from $-40{ }^{\circ} \mathrm{C}$ to $+60{ }^{\circ} \mathrm{C}$. PET has a low coefficient of friction and low hygroscopicity. The total operating temperature range of polyethylene terephthalate products is from $-60^{\circ} \mathrm{C}$ to $+170^{\circ} \mathrm{C}$.

PET is a good dielectric. The electrical properties of polyethylene terephthalate at temperatures up to $+180{ }^{\circ} \mathrm{C}$, even in the presence of moisture, change slightly. By its resistance to aggressive environment, PET has a high chemical resistance to acids, alkalis, salts, alcohols, paraffin, mineral oils, gasoline, fats, ether. It has increased resistance to water vapor. At the same time, PET is soluble in acetone, benzene, toluene, ethyl acetate, carbon tetrachloride, chloroform, methylene chloride and methyl ethyl ketone.

PET is characterized by excellent plasticity in a cold and heated state.

Thermal destruction of PET occurs in the temperature range $+290{ }^{\circ} \mathrm{C} \ldots+310{ }^{\circ} \mathrm{C}$. Destruction occurs statistically along the polymer chain. The main volatile products are terephthalic acid, acetaldehyde and carbon monoxide. At $+900{ }^{\circ} \mathrm{C}$ a large number of various hydrocarbons is generated. Mostly volatile products consist of carbon dioxide, carbon monoxide and methane.

To increase thermal, light, fire resistance, friction and other properties, various additives are introduced into PET. The methods of chemical modification with various dicarboxylic acids and glycols, which are added during the synthesis of PET into the reaction mixture, are also used.

Plugging materials must comply with certain technical and technological requirements. Their compliance largely determines the technical and economic efficiency of the work. Comparison of the compliance of well-known plugging materials and PET with these requirements (Table 3) allows us to conclude that PET may well be recommended for use to isolate absorbing horizons.

The analysis of used plugging materials allows us to divide them into three groups (Fig. 2). The presented classification of plugging materials is based on the processes that result in a plugging stone or gel of hydration, polymerization or phase transition.

Analysis of all technological operations and methods for their implementation shows that the choice of the necessary technological scheme can be made on the basis of the method of delivery of the TPM to the zone of complication [48 - 57].

Upon delivery of the TBM along the well, three schemes of technological operations are possible. In the diagrams shown in fig. 3 and fig. 4 TPM is melted by the heat of the drilling fluid, and in Fig. 5 - by contact method.

The first scheme (Fig. 3) provides for performing six operations in a certain sequence. Here, between heating the drilling fluid and melting of the TPM, it is necessary to perform operations for lifting the heater and delivering the TPM, which will lead to loss of heat and 
time. Therefore, when determining the heating temperature of the drilling fluid, it is necessary to introduce a correction factor for these losses. In the second technological scheme, the delivery of the TPM is allowed before the heater is lifted to the surface, i.e., the delivery and heating operations can be combined in time.

Table 3. Compliance of plugging materials with technical and technological requirements

\begin{tabular}{|c|c|c|c|c|}
\hline \multirow{2}{*}{ Requirement to } & \multicolumn{4}{|c|}{ Plugging material } \\
\hline & cement & bitumen & sulfur & PET \\
\hline \multicolumn{5}{|l|}{ Matrix (melt) } \\
\hline Good fluidness & + & + & + & + \\
\hline The ability to dive into fractures & + & + & + & + \\
\hline Sedimentation stability & - & - & + & + \\
\hline Inactivity in environment & - & + & + & + \\
\hline Adjustability of rheology & + & + & + & + \\
\hline \multicolumn{5}{|l|}{ Plugging stone } \\
\hline Good adhesiveness with rocks & - & - & - & - \\
\hline Stability to scouring action of striatal waters & + & + & + & + \\
\hline High drill ability & + & - & + & + \\
\hline Ability to relax & + & - & + & + \\
\hline Water tightness & + & + & + & + \\
\hline High physical and mechanical properties & + & - & - & + \\
\hline Low friction coefficient & - & - & - & + \\
\hline \multicolumn{5}{|l|}{ Raw material stock } \\
\hline Be abundant & + & + & + & + \\
\hline Price per ton, UAH & 1500 & 8000 & 12500 & 3000 \\
\hline Properties do not deteriorate with time & - & - & + & + \\
\hline Environmentally-friendly & + & + & + & + \\
\hline
\end{tabular}

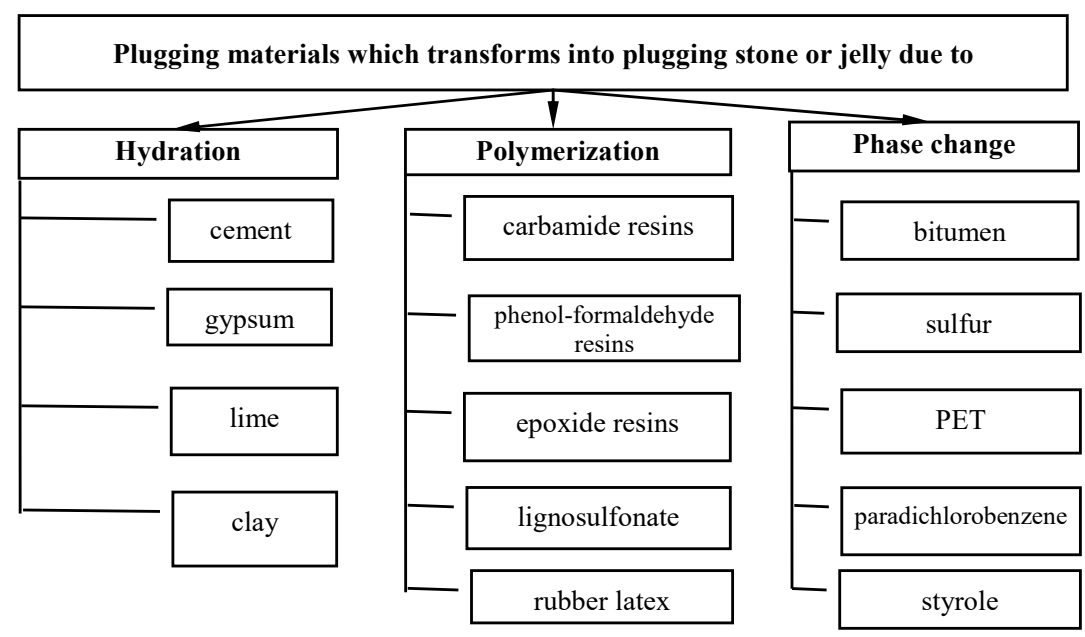

Fig. 2. Classification of plugging materials.

In this case, more favorable conditions are provided for melting TPM. Implementation of the second technology is possible with sufficient gap between the walls of the well and the walls of the heater case. The case must be made of materials resistant to aggressive environments. When applying the third technology, in case of absence of the column of liquid in the well, contact type of electric heaters are used. 
The second scheme. As in the previous case, there are three options of completing delivery of pipes along the string (Fig. 4). To implement the first two technologies heaters of small diameter are needed so that they can be transported along the drill string. In the first case the heater is removed from the well after heating drilling fluid and then TPM granules are poured through the drill string. This sequence of operations leads to a specific loss of heat in drilling fluid at the bottom hole. In the second case, these losses can be eliminated. However the lift of heater body inside the pipe string becomes more complicated because of the remains of the melt of TPM. The third method requires fewer operations. In this case the heater of large diameter can be used as it is pulled down into the well after lifting the drill string. In this technology TPM melts due to contact method.

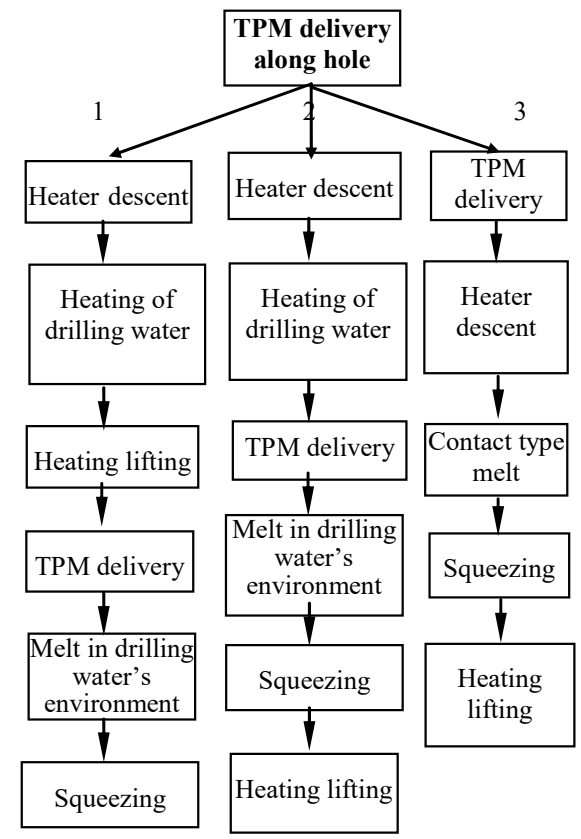

Fig. 3. Isolation technology of absorbing horizons during TPM delivery along the hole.

The third scheme. During TPM delivery in the container (Fig. 5), there are two methods of completing an activity. In the first case, the container is pulled down into the borehole and then it unleashes TPM after landing. After removing the container from the hole the heater is pulled down to begin melting the TPM by contact method. A special device is required to follow the technological steps of the second technological scheme. It is pulled down into the well on a cable that combines the heater, the container and a fill valve of releasing the melt on the bottom hole.

After the analytic and experimental research, with regard to the geological and technical conditions of drilling, the technological schemes discussed in Figs. 3-5, based on the presented technological schemes of conducting plugging operations, the method can be recommended for use in industrial environment,. In this case, general requirements lodged to the technology of plugging of absorbing horizons using TPM are to be met.

According to some researchers, the usage of inert materials for plugging the porous rocks does not cause much difficulty. The proposed technology is recommended to be used for plugging fractured absorbing horizons with a minimum opening of cracks $0.5 \mathrm{~mm}$. Process water and clay mud can be used as drilling fluid. 


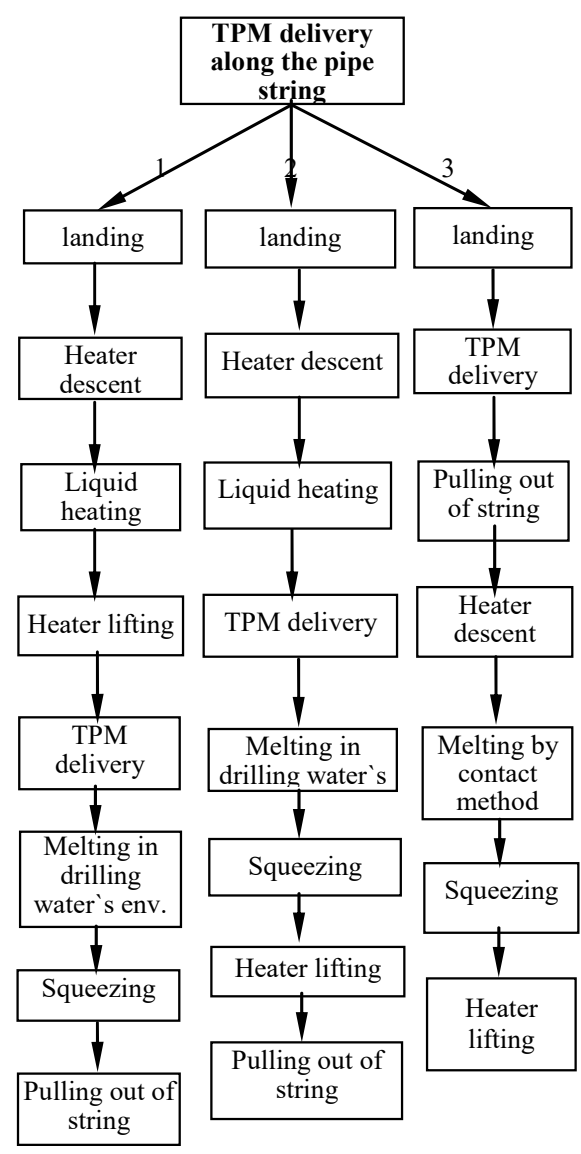

Fig. 4. The technology of isolation of absorbing horizons during TPM delivery along the drill string.

For the conditions: the well is piled up by the pipe string with its open part which not exceeds $50 \mathrm{~m}$, the well is vertical and not deeper than $150-200 \mathrm{~m}$, and there are no cavities, the column of drilling fluid is above of the roof of the absorbing horizon at least for $20-25 \mathrm{~m}$. In this case it is possible to use the technological scheme with TPM delivery along the borehole (Fig. 3). This technological scheme is the most appropriate for these conditions because its technological operations are consistent, and because emergency situations related to the tool pulling are impossible in the well.

During the process of drilling wells, particularly in the Donbas, there are cases when the well is drilled with complete fluid loss. This caused by intensive development, high fracturing and permeability of the rocks which form the walls of the well. At the same time, at the bottom hole there is an insignificant amount of drilling fluid or its full absence. For these types of wells it is recommended to use the technological scheme shown in Fig. 3. At the same time, it is possible to do the delivery of the material by its backfill through the top of borehole, and at great depth - along the drill string (Fig. 4). While performing this technological scheme, there should be no core fragments in the core tube. For melting granulated TPM, downhole heat sources of contact type are applied.

The most functional, simple and technological way of plugging is the method of TPM delivery in the container (Fig. 5). 


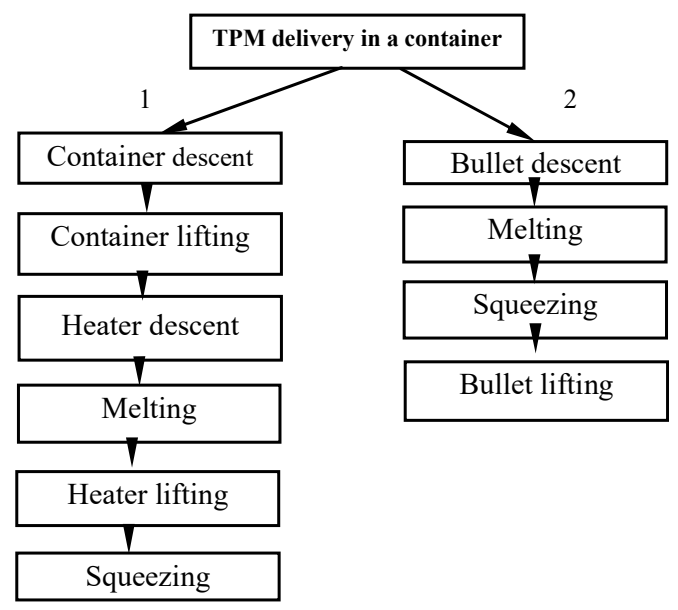

Fig. 5. The technology of isolation of absorbing horizons while TPM delivery in a container.

Melting is realized by way of contact. The disadvantage of this method is the limited volume of the container. In this case, the minimum number of process steps will be required for isolation the absorptive horizon. The method of TPM delivery to the downhole in a container with attached cable has the best perspectives. It can be used for wells up to 9000 meters long with minimal waste of time and energy.

\section{Conclusions}

This work considers the isolation technology of absorption TPM horizons. For its implementation, the following operations should be done: TPM delivery to the downhole, melting and strangulation TPM to the absorbing channels. For various geological and technical conditions of boring, technological schemes of isolation of the absorbing TPM horizons are proposed. The possibility to use PET as plugging material is proved.

Authors express gratitude for the help and consultations during work performing for director of LTD Industrially-geological group "Dniprohidrobud" of Oleh Mostinets.

\section{References}

1. Bondarenko, V., Kovalevs'ka, I., \& Fomychov, V. (2012). Features of carrying out experiment using finite-element methodat multivariate calculation of mine massif - combined support system. Geomechanical Processes During Underground Mining - Proceedings of the School of Underground Mining, 7-13. https://doi.org/10.1201/b13157-3

2. Bondarenko, V.I., Kharin, Ye.N., Antoshchenko, N.I., \& Gasyuk, R.L. (2013). Basic scientific positions of forecast of the dynamics of methane release when mining the gas bearing coal seams. Naukovyi Visnyk Natsionalnoho Hirnychoho Universytetu, (5), 24-30.

3. Lozynskyi, V., Dychkovskyi, R., Saik, P., Falshtynskyi, V. (2018). Coal Seam Gasification in Faulting Zones (Heat and Mass Balance Study). Solid State Phenomena, (277), 66-79. https://doi.org/10.4028/www.scientific.net/SSP.277.66

4. Bondarenko, V., Maksymova, E., \& Koval, O. (2013). Genetic classification of gas hydrates deposits types by geologic-structural criteria. Annual Scientific-Technical Collection-Mining of Mineral Deposits 2013, 115-119. https://doi.org/10.1201/b16354-21 
5. Bondarenko, V., Kovalevs'ka, I., \& Ganushevych, K. (2014). Progressive Technologies of Coal, Coalbed Methane, and Ores Mining. (2014). https://doi.org/10.1201/b17547

6. Khomenko, O., Kononenko, M., Myronova, I., \& Sudakov, A. (2018). Increasing ecological safety during underground mining of iron-ore deposits deposits. Naukovyi Visnyk Natsionalnoho Hirnychoho Universytetu, (2), 29-38.

7. Bondarenko, V., Lozynskyi, V., Sai, K., \& Anikushyna, K. (2015). An overview and prospectives of practical application of the biomass gasification technology in Ukraine. New Developments in Mining Engineering 2015: Theoretical and Practical Solutions of Mineral Resources Mining, 27-32. https://doi.org/10.1201/b19901-6

8. Kovalevs'ka, I., Symanovych, G., \& Fomychov, V. (2013). Research of stress-strain state of cracked coal-containing massif near-the-working area using finite elements technique. Annual Scientific-Technical Collection - Mining of Mineral Deposits 2013, 159-163. https://doi.org/10.1201/b16354-28

9. Lozynskyi, V.H., Dychkovskyi, R.O., Falshtynskyi, V.S., \& Saik, P.B. (2015). Revisiting possibility to cross disjunctive geological faults by underground gasifier. Naukovyi Visnyk Natsionalnoho Hirnychoho Universytetu, (4), 22-28.

10. Sdvizhkova, Ye.A., Babets, D.V., \& Smirnov, A.V. (2014). Support loading of assembly chamber in terms of Western Bonbas plough longwall. Naukovyi Visnyk Natsionalnoho Hirnychoho Universytetu, (5), 26-32.

11. Falshtyns'kyy, V., Dychkovs'kyy, R., Lozyns'kyy, V., \& Saik, P. (2013). Justification of the gasification channel length in underground gas generator. Annual Scientific-Technical CollectionMining of Mineral Deposits 2013, 125-132. https://doi.org/10.1201/b16354-23

12. Kovalevska, I., Zhuravkov, M., Chervatiuk, V., Husiev, O., \& Snihur, V. (2019). Generalization of trends in the influence of geomechanics factors on the choice of operation modes for the fastening system in the preparatory mine workings. Mining of Mineral Deposits, 13(3), 1-10. https://doi.org/10.33271/mining13.03.001

13. Kyrychenko, Y., Samusia, V., Kyrychenko, V., \& Goman, O. (2012). Experimental investigation of aeroelastic and hydroelastic instability parameters of a marine pipeline. Geomechanical Processes During Underground Mining - Proceedings of the School of Underground Mining, 163-167.

14. Falshtynskyy, V., Dychkovskyy, R., Lozynskyy, V., \& Saik, P. (2012). New method for justification the technological parameters of coal gasification in the test setting. Geomechanical Processes During Underground Mining - Proceedings of the School of Underground Mining, 201208. https://doi.org/10.1201/b13157-35

15. Saik, P.B., Dychkovskyi, R.O., Lozynskyi, V.H., Malanchuk, Z.R., \& Malanchuk, Ye.Z. (2016). Revisiting the underground gasification of coal reserves from contiguous seams, Naukovyi Visnyk Natsionalnoho Hirnychoho Universytetu, (6), 60-66.

16. Pivnyak, G., Dychkovskyi, R., Smirnov, A., \& Cherednichenko, Y. (2013). Some aspects on the software simulation implementation in thin coal seams mining. Energy Efficiency Improvement of Geotechnical Systems, 1-10. https://doi.org/10.1201/b16355-2

17. Kovalevska, I., Barabash, M., \& Snihur, V. (2018). Development of a research methodology and analysis of the stress state of a parting under the joint and downward mining of coal seams. Mining of Mineral Deposits, 12(1), 76-84. https://doi.org/10.15407/mining12.01.076

18. Khomenko, O. (2012). Implementation of energy method in study of zonal disintegration of rocks. Naukovyi Visnyk Natsionalnoho Hirnychoho Universytetu, (4), 44-54.

19. Zhanchiv, B., Rudakov, D., Khomenko, O., \& Tsendzhav, L. (2013). Substantiation of mining parameters of Mongolia uranium deposits. Naukovyi Visnyk Natsionalnoho Hirnychoho Universytetu, (4), 10-18.

20. Khomenko, O., Kononenko, M., \& Myronova, I. (2013). Blasting works technology to decrease an emission of harmful matters into the mine atmosphere. Annual Scientific-Technical CollectionMining of Mineral Deposits 2013, 231-235. https://doi.org/10.1201/b16354-43 
21. Vladyko, O., Kononenko, M., \& Khomenko, O. (2012). Imitating modeling stability of mine workings. Geomechanical Processes During Underground Mining - Proceedings of the School of Underground Mining, 147-150. https://doi.org/10.1201/b13157-26

22. Khomenko, O., Tsendjav, L., Kononenko, M., \& Janchiv, B. (2017). Nuclear-and-fuel power industry of Ukraine: production, science, education. Mining of Mineral Deposits, 11(4), 86-95. https://doi.org/10.15407/mining11.04.086

23. Cook, J., Growcock, F., Guo, Q., Hodder, M., \& van Oort, E. (2011). Stabilizing the wellbore to prevent lost circulation. Oilfield Review, 23(4), 26-35.

24. Ashok Kumar Santra, B.R. Reddy, \& Mfon Antia (2007). Designing Cement Slurries for Preventing Formation Fluid Influx After Placement. International Symposium on Oilfield Chemistry, (28) February-2 March, Houston, Texas, U.S.A. SPE-106006-MS https://doi.org/10.2118/106006-MS

25. Fedorov, B., Ratov, B., \& Sharauova, A. (2017). Development of the model of petroleum well boreability with PDC bore bits for Uzen oil field (the Republic of Kazakhstan) Eastern-European Journal of Enterprise Technologies, 3(1(87), 16-22. https://DOI:10.15587/1729-4061.2017.99032

26. Yu, H., Li, L., Zheng, J., Ji, W., Qin, X., Fu, X., \& Gao, W. (2016). New Method of Steam Channeling Plugging in Horizontal Wells of Heavy Oil Steam Stimulation. In SPE Latin America and Caribbean Heavy and Extra Heavy Oil Conference. SPE-181173-MS.

27. Liu, Y., Song, T., \& Xu, Y. (2016). A new evaluation method for micro-fracture plugging in hightemperature deep wells and its application: A case study of the Xushen Gas Field, Songliao Basin. Natural Gas Industry, 3(2), 158-164.

28. Sudakov, A.K., Dreus, A.Yu., Khomenko, O.Ye., \& Sudakova, D.A. (2017). Analitic study of heat transfer in absorbing horizon of boreholes in the formation of protection cryogenic plugging material. Naukovyi Visnyk Natsionalnoho Hirnychoho Universytetu, 3(159), 32-46.

29. Brazhenenko, A.M., Goshovskiy, S.V., \& Sudakov, A.K. (2007). Tamponazh gornykh porod pri burenii geologorazvedochnykh skvazhin legko-plavkimi materialami. Kyiv: Ukrainskyi derzhavnyi heoloho-rozviduvalnyi instytut.

30. Sudakova, D.A. (2018). Substantiation of parameters of technology insulation of absorbing horizons of boreholes. $\mathrm{PhD}$ Thesis. Ivano-Frankivsk, Ukraine: Ivano-Frankivsk National Technical University of Oil and Gas.

31. Sudakov, A.K. (1999). Modern technologies and materials, applied for liquidation of absorptions of washing liquid. Naukovyi Visnyk Natsionalnoho Hirnychoho Universytetu, (5), 98-102.

32. Sudakova, D.A. (2017). Rezul'taty analiza tekhnologiy tamponirovaniya pogloshchayushchikh gorizontov burovykh skvazhin. In Shkola pidzemnoi rozrobky (pp. 101-102). Berdiansk, Ukraine: Natsionalnyi hirnychyi universytet.

33. Sudakov, A.K. (2000). Tekhnologiya izolyatsii zon pogloshcheniya burovykh skvazhin s primeneniem termoplastichnykh materialov. PhD Thesis. Dnipropetrovsk, Ukraine: NHU.

34. Taninskiy, P.Yu. (2000). Vybor legkoplavkikh svyazuyushchikh materialov dlya ekologicheski chistogo bestrubnogo krepleniya skvazhin. PhD Thesis. Sankt-Peterburg, Russia.

35. Kuzin, Yu. L., \& Sudakova, D.A. (2016). O vozmozhnosti primeneniya bytovykh otkhodov dlya izolyatsii pogloshchayushchikh gorizontov burovykh skvazhin. Porodorazrushayushchiy $i$ metalloobrabatyvayushchiy instrument - tekhnika i tekhnologiya ego izgotovleniya i primeneniya, (19), 92-96.

36. Isakova, M., \& Sudakova, D. (2016). Thermoplastic materials on the basis of polyethyleneтеrephthalate. In 11th International Forum for Students and Young Researchers, (p. 62). Dnipropetrovsk, Ukraine: Natsionalnyi hirnychyi universytet.

37. Sudakova, D.A. (2017). O vozmozhnosti primeneniya bytovykh otkhodov v kachestve tamponazhnogo termoplastichnogo materiala. In Molod: nauka ta innovatsii (pp. 34-35). Dnipropetrovsk, Ukraine: Natsionalnyi hirnychyi universytet.

38. Sudakova, D.A. (2017). Mekhanicheskie svoystva tamponazhnogo termoplastichnogo materiala na osnove polietilentereftalata. Visti Donetskoho Hirnychoho Instytutu, (2), 107-116. 
39. Kuzin, Yu. L., Sudakova, D.A., \& Luk'yanenko, M.V. (2017). Rezul'taty issledovaniy mekhanicheskikh svoystv tamponazhnogo termoplastichnogo kompozitsionnogo materiala na osnove polietilentereftalata. In Forum Hirnykiv (pp. 242-247). Dnipro, Ukraine: Natsionalnyi hirnychyi universytet.

40. Sudakova, D.A. (2018). Rezul'taty stendovykh issledovaniy termomekhanicheskoy tekhnologii izolyatsii pogloshchayushchikh gorizontov tamponazhnimi termoplastichnymi kompozitsionnymi materialami. Zbirnyk naukovykh prats Natsionalnjho hirnychoho universytetu, (54), 285-298.

41. Kozhevnikov, A.A., Dreus, A.J., Lysenko, K.Ye., \& Sudakov, A.K. (2013). Research of heat transfer in cryogenic gravel filter at his transporting on barrel of drillhole. Naukovyi Visnyk Natsionalnoho Hirnychoho Universytetu, (6), 49-54.

42. Dreus, A., Kozhevnikov, A., Lysenko, K., \& Sudakov, A. (2016). Investigation of heating of the drilling bits and definition of the energy efficient drilling modes. Eastern-European Journal of Enterprise Technologies. Technologies, 3(7(81)), 41-46. https://doi.org/10.15587/1729$\underline{4061.2016 .71995}$

43. Ziborov, K.A., Protsiv, V.V., Blokhin, S.Ye., \& Fedoriachenko, S.O. (2014) Applicability of computer simulation while designing mechanical systems of mining rolling stock. Naukovyi Visnyk Natsionalnoho Hirnychoho Universytetu, (6), 55-59.

44. Kuzin, J., Mostinets, O., Sudakova, D., \& Isakova, M. (2017). Isolation technology for swallowing zones by thermoplastic materials on the basis of polyethyleneтerephthalate. Naukovyi Visnyk Natsionalnoho Hirnychoho Universytetu, 1(157), 34-39.

45. Sudakov, A., Dreus, A., Sudakova, D., \& Khamininch, O. (2018). The study of melting process of the new plugging material at thermomechanical isolation technology of permeable horizons of mine opening. E3S Web of Conferences, (60), 1-10. https://doi.org/10.1051/e3sconf/20186000027

46. Sudakov, A., Dreus, A., Ratov, B., \& Delikesheva, D. (2018). Theoretical bases of isolation technology for swallowing horizons using thermoplastic materials. News of the national academy of sciences of the republic of Kazakhstan, 2(428), 72-80.

47. Sudakov A.K. Khomenko O.Ye., Isakova M. L., \& Sudakova, D.A. (2016). Concept of numerical experiment of isolation of absorptive horizons by thermoplastic materials. Naukovyi Visnyk Natsionalnoho Hirnychoho Universytetu, 5(155), 12-16.

48. Grydzhuk, J., Chudyk, I., Velychkovych, A., \& Andrusyak, A. (2019). Analytical estimation of inertial properties of the curved rotating section in a drill string. Vostochno-Evropeyskiy Zhurnal Korporativnykh Tekhnologiy, 1(7-97), 6-14.

49. Vytyaz, O., Chudyk, I., \& Mykhailiuk, V. (2015). Study of the effects of drilling string eccentricity in the borehole on the quality of its cleaning. Novye razrabotki v gornom dele 2015: teoreticheskie i prakticheskie resheniya razrabotki poleznykh iskopaemykh, (1), 591-595.

50. Protsiv, V., Ziborov, K., \& Fedoriachenko, S. (2013). On formation of kinematical and dynamical parameters of output elements of the mine vehicles in transient motion. Naukovyi Visnyk Natsionalnoho Hirnychoho Universytetu, (4), 65-70.

51. Dreus, A.J., Sudakov, A.K., Kozhevnikov, A.A., \& Vahalin, J.M. (2016). Study on thermal strength reduction of rock formation in the diamond core drilling process using pulse flushing mode. Naukovyi Visnyk Natsionalnoho Hirnychoho Universytetu, 3(153), 5-9.

52. Khomenko, O.Ye., Sudakov, A.K., Malanchuk, Z.R., \& Malanchuk, Ye.Z. (2017). Principles of rock pressure energy usage during underground mining of deposits. Naukovyi Visnyk Natsionalnoho Hirnychoho Universytetu, 2(158), 34-43.

53. Kozhevnykov, A.O., Dreus, A.Yu., Baochang, Liu, \& Sudakov, A.K. (2018). Drilling fluid circulation rate infuence on the contact temperature during borehole drilling. Naukovyi Visnyk Natsionalnoho Hirnychoho Universytetu, 1(163), 35-43.

54. Sudakova, D.A. (2017). Netraditsionnaya tekhnologiya bor'by s pogloshcheniem burovykh rastvorov v skvazhinakh. Visti Donetskoho Hirnychoho Instytutu, (1), 227-233.

55. Kuzin, Yu. L., \& Sudakova, D.A. (2017). Termomekhanichniy sposib tamponuvannya proniknikh gorizontiv burovikh sverdlovin. In Porodorazrushayushchiy $i$ metalloobrabatyvayushchiy instrument - tekhnika i tekhnologiya ego izgotovleniya i primeneniya (pp. 98-102). Truskavets, 
Ukraine: Institut sverkhtverdykh materialov.

56. Rifert, V.G., Sereda, V.V. (2015). Condensation inside smooth horizontal tubes: Part 1. Survey of the methods of heat-exchange prediction. Thermal Science, 19(5), 1769-1789.

57. Law, B.E., Ulmishek, G.F., Clayton, J.L., Kabyshev, B.P., Pashova, N.T., \& Krivosheya, V.A. (1998). Basin-centered gas evaluated in Dnieper-Donets basin, Donbas foldbelt, Ukraine. Oil and Gas Journal, 96(47), 74-78. 